Sullivan, A., Zimdars, A. and Heath, A. (2010) 'The Social Structure of the 14-16

Curriculum in England'. International Studies in the Sociology of Education. 20(1): 5-21.

Special Issue: Festschrift for Geoffrey Walford.

\title{
The social structure of the 14-16 Curriculum in England
}

Abstract: This paper examines the stratification of the curriculum according to parents' education, gender, ethnicity and school sector in England, focussing on year 10 subject choices. Using the Longitudinal Study of Young People in England, we analyse both year 10 subject choices and the factors which may motivate these choices, such as liked and disliked subjects, attitudes to subject choice, and the extent to which choices were shaped by parents, teachers or the young people themselves. The social structure of curriculum choice is mapped using Multiple Correspondence Analysis, which reveals the hierarchy of subjects.

Key words: Curriculum, inequality, gender, social class, ethnicity, schooling.

Authors:

Dr. Alice Sullivan

Institute of Education, University of London

Dr. Anna Zimdars

Institute for Social Change, University of Manchester

Prof. Anthony Heath

Department of Sociology, University of Oxford 


\title{
The social structure of the 14-16 Curriculum in England
}

\author{
Abstract: This paper examines the stratification of the curriculum \\ according to parents' education, gender, ethnicity and school sector \\ in England, focussing on year 10 subject choices. Using the \\ Longitudinal Study of Young People in England, we analyse both year \\ 10 subject choices and the factors which may motivate these choices, \\ such as liked and disliked subjects, attitudes to subject choice, and the \\ extent to which choices were shaped by parents, teachers or the young \\ people themselves. The social structure of curriculum choice is \\ mapped using Multiple Correspondence Analysis, which reveals the \\ hierarchy of subjects.
}

\section{Introduction}

The increasing complexity of curricular arrangements in England for 14-16 year olds raises important questions about the extent to which young people and their families have the knowledge and understanding to navigate their way through the range of options and hence make informed 'choices' (Sullivan and Unwin 2009). This paper seeks to describe the social structure of the year 10 curriculum, and analyse the factors that influence young people's choices. Year 10 is the third year of secondary school, when students are around 13 years old, and is the year in which important decisions are made regarding the subjects to be studied in the following two years, leading up to terminal examinations - the General Certificate of Secondary Education (GCSE).

School league tables treat all GCSE or A level examination passes as being of equal value. (A levels are prestigious 'college-track' examinations taken at age 18 by a minority of students). In reality, some subjects have greater prestige than others, and failure to take particular subjects at GCSE and A level limits the future options available to students. The fact that some subjects have greater currency than others may not be transparent to students. Meanwhile, the fact that league tables of school performance do not recognise the differing value of different subjects has led to concerns that schools are maximising their performance at the benchmark five $\mathrm{A} *_{-} \mathrm{C}$ level by putting students in for 'soft' options, and avoiding more challenging subjects. (Within the English system, the proportion of students with at least five GCSE passes at least grade $\mathrm{C}$ is seen as an important indicator of school performance). When 
GCSEs were introduced in 1988, curriculum options were fairly limited, and students' options occurred within rigid constraints. For example, a compulsory modern language up to age 16 was the norm. Concerns have been raised, including by the Conservative shadow education secretary, that prestigious options such as languages and single sciences are declining in state schools (BBC NEWS 29/04/09 ). Of course, differences in the curriculum offered to state and private students are not new. But it seems likely that the structure of incentives faced by state schools is exacerbating those differences, and changing the curriculum that is offered to state students. As well as the division between state and private schools, it is important to consider differences within the state sector. The current government has encouraged a proliferation of different types of school, and, in the schools quasi-market, some parents compete for places at desirable schools for their children, and some schools compete for the most desirable children (Ball 2003).

Unlike other European qualifications such as the International or European Baccalaureate or the German Abitur, the GCSE curriculum in England and Wales allows students to narrow their future choices at a relatively early age. The core curriculum offered by different types of school is determined by the national curriculum, but the statutory curriculum core narrows for students of age 14 and above. Only English, maths, science, Physical Education, citizenship and religion are covered by the statutory curriculum for students aged 14-16. Therefore, there is scope for schools to have a considerable impact on the curriculum that is available to and taken up by students at this stage. In turn, the options taken at GCSE level are likely to determine, to a greater or lesser extent, the options that students take up at the next levels.

The rational choice approach to educational decision making (Boudon 1974; Breen and Goldthorpe 1997) has tended to neglect factors such as the amount of information that individuals have access to in making decisions, and the way in which their decisions are framed. Within this framework, social class differences in the educational pathways followed by young people are due to differences in the perceived constraints and returns to education faced by people from different social class groups. Rational choice theorists generally assume that beliefs and attitudes do not vary by social category, and do not concern themselves with cultural factors (Sullivan 2006). For rational choice theorists, even if individuals do not really make decisions by rationally weighing up the costs and benefits, they generally behave as though this is what they are doing. Thus factors such as the extent to which decisions are 
made by parents, teachers, or children themselves can be seen as irrelevant within this approach. In contrast, much qualitative evidence has suggested that social class and ethnicity affect the way in which choices are determined. Ball et. al. (2003) distinguish between 'embedded choosers' for whom the trajectory leading to higher education is part of a cultural script or 'normal biography', and contingent choosers who have little information on which to base their choices, little relevant social capital, and for whom choice is based on short-term factors and not strongly linked to imagined long term futures.

Ball's work is informed by Bourdieu's (1977) approach to educational inequalities, which emphasises that middle class families give their children the cultural capital needed to succeed in high status academic curricula. The concept of cultural capital has been interpreted in various ways, but there is a consensus that cultural practices associated with the educated middle-classes, such as reading, are linked to educational attainment (Crook, 1997, Sullivan, 2001, De Graaf et al., 2000). Hansen and Mastekaasa (2006) show that the advantage children from privileged backgrounds have in their university performance is greatest in the professional and cultural fields of study, and suggest that the cultural capital associated with a middle-class background is of most value in meeting the diffuse standards of assessment in these fields. But Bourdieu focuses on class, and has little to say about gender or ethnicity, although others have applied his ideas to these issues (Adkins and Skeggs 2004). Modood (2004) argues that the Bourdieusian perspective does not allow us to understand why some ethnic minorities show high levels of persistence in the education system, often despite disadvantaged social class backgrounds, and that this is better understood in terms of high aspirations and parental discipline. Subject specialisms also vary by ethnic group - for example South-Asians take more technical subjects (Kotecha 2007). Risk aversion, as well as parental involvement, may be implicated in these decisions, but this issue has been underresearched.

Gender segregation of curricula and qualifications has persisted in some areas despite girls' increased absolute educational attainment, although there have been changes such as women's increased entry into medicine and law. This segregation of the curriculum is implicated in the gender segregation of the labour market. While some authors explain this in terms of early socialisation, others stress the effect of ongoing discriminatory pressures (Jacobs 1989). Academic self-concept, i.e. beliefs regarding one's own ability, in different fields is highly gendered (Sullivan 2009). Explanations for this include socialisation by parents, peers, and the media, and gender biases in the curriculum and the way it is delivered 
(Eccles, 1987, Jacobs, et al., 2005, Kelly, 1985, Linver and Davis-Kean, 2005). The vocational tracks typically pursued by working-class girls appear particularly limiting in terms of future prospects.

This article examines the stratification of the curriculum according to parents' education, gender, ethnicity and school sector in England, focussing on year 10 subject choices. Year 10 subject choices are important, because they constrain young people's future trajectories. Our analyses describe the differences in the curriculum followed by different groups of students, and differences in the way they perceive a range of academic subjects and the factors that influence their choices.

\section{Data and Methods}

We base our analysis on the Longitudinal Study of Young People in England (LSYPE). This study is managed by the Department for Children, Schools and Families (DCSF), and is a major innovative panel study of young people which began in 2004 with a sample of young people were aged between 13 and 14. It brings together data from a number of different sources, including both annual interviews with young people and their parents and administrative sources. LSYPE includes sample boosts for minority groups, and $36 \%$ of the wave 1 sample ( $\mathrm{N}=15$ 416) were from minority groups (Strand 2007). The analyses reported here are weighted appropriately to take account of the sample design.

This paper examines the social structure of the year 10 curriculum using both standard descriptive techniques and Multiple Correspondence Analysis (MCA). In 'Homo Academicus' (1984), Bourdieu shows that, even among university professors, academic disciplines are socially differentiated. Using data from various sources, largely relating to the 1960s, he shows that, compared to professors in the arts and humanities, professors of law and medicine had higher social origins, were more likely to have attended private schools, were more likely to be Parisian, to be men, and to be married with a large number of children. Bourdieu goes on to use MCA to describe the 'social space' of the faculties in terms of variables relating to power and prestige.

Multiple Correspondence Analysis (MCA) is a form of data analysis that has a long tradition within the sociology of culture, and was most famously used by Bourdieu, for example in 'Distinction' (1984). More recently, MCA has been used by Bennett et. al. (2008), Gayo-Cal et. al. (2006) and Le Roux et. al. (2008) to analyse British data on cultural participation and 
tastes. MCA does not allow for an analysis which partials out certain effects in order to disentangle the relationships between variables (Chan and Goldthorpe 2007). Conversely, MCA allows us to focus on the 'big picture', avoiding the common pit-fall associated with regression analysis of focussing only on whether a particular effect is statistically significant once other factors have been controlled, rather than on the main patterns in the data. Rather than modelling the data according to a preconceived theoretical model, MCA can be seen as an inductive, data-driven technique, allowing patterns in the data to reveal themselves (Benzecri 1973).

Correspondence Analysis is often referred to as a special version of Principal Components Analysis (PCA) (Blasius and Greenacre 2006). The percentage inertia explained by axes takes the place of the percentage variance of PCA. Unlike factor analysis, correspondence analysis is a nonparametric technique which makes no distributional assumptions (Wuggenig 2007). It also has the advantage of being particularly suited to the analysis of categorical variables. Active points are the category values of the variables used to compute the dimensions used to plot the correspondence map. Supplementary points do not contribute to the construction of the social space, but are superimposed on this space. As in PCA, as few dimensions as possible are used for interpretation. In the analyses presented here, planar maps are used, showing pairs of dimensions at a time.

\section{Analysis}

Table 1:

Table 1 indicates that year 10 subject choices are clearly patterned by gender, ethnicity, schooling and parental background. First of all, subjects are clearly gendered in their popularity. Boys were more likely than girls to study Electronics and related subjects, graphics and design, business and PE. Perhaps surprisingly, the difference in the uptake of Mathematics and Statistics favouring boys, though statistically significant, was substantively modest at 1.3 percentage points. There was also no significant gender difference in the take up of triple-award sciences (that is Biology, Chemistry and Physics taken as separate subjects). Female students were over-represented in arts subjects such as languages, art and drama, and in applied subjects in the areas of health, food and textiles.

The ethnic composition of subjects also varies for both academic and applied subjects. White students are over- represented in PE, engineering and related fields, the arts and history and 
geography. Pakistani, Bangladeshi and black students are substantially over-represented in both citizenship and religion GCSEs compared to white students, but this does not apply to Indian students. Since parental education is not related to representation in GCSE religion, this is intriguing, and may reflect family religiosity. There are both commonalities and differences between the South Asian students - Indian, Bangladeshi and Pakistani. Obviously, Indian families are relatively affluent and highly educated, and their option choices largely reflect this, but they are relatively unlikely to take arts subjects, and they appear similar to the Pakistani and Bangladeshi group on this dimension. We group Pakistanis and Bangladeshis together due to their similar patterns of curriculum choice. Indians are well represented in business and Maths and Statistics, whereas Bangladeshi and Pakistani young people are disproportionately likely to opt for textiles and health. Black students are over-represented in arts subjects but under-represented in triple sciences.

The type of secondary school also has a significant association with subject choice patterns. We distinguish between private schools, comprehensive schools and foundation or voluntary aided schools. Foundation and voluntary aided schools are state schools with independent trustees, and for which the governing body is the employer of the school staff and acts as the admissions authority for the school. Clearly this measure does not capture the full diversity within the state sector, but a simple measure is useful to show the main patterns parsimoniously. Private school students are more likely to study prestigious academic subjects such as sciences, history, geography, languages and the arts than their peers in the state school system. They are less likely to study for any applied subjects and are also underrepresented among those taking core subjects such as citizenship, religion or PE as full GCSEs. But Table 1 also indicates that, within the state school system, there are differences between the foundation schools and other state schools. Those in foundation schools were in some respects more similar to their peers in the private sector than to other state school students. Foundation school students are more likely to study sciences, languages, history and geography and less likely to study applied subjects. Unlike private school students, however, they are much more likely to take religion as a full GCSE, which perhaps reflects the representation of religious schools within the foundation sector. Students in comprehensive schools are over-represented in applied subjects and are comparatively underrepresented in languages, single sciences and history or geography.

We also examine parental educational status (at least one parent with a degree qualification versus no graduate parent). Clearly this variable is strongly linked to, though distinct from, 
social class, which we do not have the space to examine separately here. Sociologists have suggested important divisions within the middle class, including the divisions between the 'old' and 'new' middle classes, and the professional and managerial middle classes (Bernstein 1971; Power et. al. 2003; Savage and Egerton 1997; Zimdars et. al 2009), which we hope to analyse in future work. These divisions may also be reflected in the number of parents with a degree (both or just one) and the type of institution and subject area of the degree, but we do not assess this here. We find that pupils with parents who do not have degrees are much more likely to opt for applied subjects and PE. Students with graduate parents are over-represented in the humanities - geography or history, foreign languages and the arts - and are substantially more likely to take triple-award sciences.

FIGURE 1

To what extent are differences in the curriculum options followed by young people driven by different preferences for particular subjects? Figure 1 shows students' favourite and least favourite subjects according to their sex. For boys, P.E. is by far the most popular subject (32\%), whereas only $15 \%$ of girls choose this as their favourite, and $8 \%$ choose it as their least favourite. Girls are most likely to choose art as their favourite (22\%), whereas boys are less than half as likely (9\%) to choose this subject as their favourite. Maths is chosen as 'least favourite' more often than as favourite by both sexes, but especially by girls: it is the least favourite subject for $22 \%$ of girls. English is more likely to be chosen as favourite (9\%) than least favourite (7\%) for girls, but the opposite is true for boys. Boys are most likely to choose modern languages (20\%) as their least favourite subject, whereas this is the least favourite for only $13 \%$ of girls. The compulsory subject of religious studies is unpopular with both sexes, as boys and girls are both much more likely to choose it as their least favourite than as their favourite subject.

\section{FIGURE 2}

Figure 2 shows the information regarding favourite and least favourite subjects according to the parents' educational level, dividing young people with at least one graduate parent and those whose parents do not have degrees. As stated previously, parents' education is of course strongly correlated with social class, but we use parents' education in order to examine the view that families with a history of higher education may have a different relationship with the curriculum and with the process of making choices within the school system. The differences shown according to parents' education are far less striking than those 
between girls and boys. PE and art are the most common favourite subjects for students with graduate and non-graduate parents. However, the children of graduates are 50\% more likely to favour history and science (chosen by $9 \%$ in each case) than the children of non-graduates (6\% of whom chose each of these subjects). The least favourite subjects chosen by the children of graduates and non-graduates are even more similar than their favourite subjects. Mathematics and languages are clearly the least favoured subjects, followed by religious education and science. With the exception of religion, the less popular subjects have in common a reputation for being hard.

\section{FIGURE 3}

Figure 3 shows the reasons for choosing particular subjects according to the parents' educational level, and the young person's sex and ethnic group. While many of the reasons given do not vary strongly according to parents' education, it is clear that the children of graduates are less likely to agree with instrumental statements regarding choosing subjects to make sure of good exam grades, and fulfil the requirements of future courses and future jobs. The children of graduates were much less likely to feel that their choices were constrained by these pragmatic concerns. Similarly, black and Pakistani and Bangladeshi young people are more likely than whites to agree strongly with these more instrumental statements, though, in an apparent contradiction, black, Pakistani, Bangladeshi and Indian young people are also more likely than whites to agree with the statement that 'I chose these subjects because I only want to do subjects that I'm interested in'. Boys are more likely than girls to say that liking teachers and doing the same subjects as their friends are important.

The following analyses using MCA are based on 12922 cases which had valid cases for school, sex and year 10 subject choices.

FIGURE 4 AND 4B

Axis 1: 19.29

Axis 2: 14.58

We applied Multiple Correspondence Analysis to the students' year 10 subject options. This analysis is shown in figure 4 , and figure $4 \mathrm{~b}$ which magnifies the centre of the space, which is quite crowded. The horizontal axis reflects the status of the disciplines. Individual science subjects, modern languages and history cluster together in the top left quadrant, which is 
associated with young people with parents with degree level qualifications and private schooling. The left hand side of the space is occupied by applied subjects, and by not taking single sciences. The vertical axis is structured by gender, and shows the strength of the gender divide within applied subjects, with 'male' subjects such as applied engineering in the bottom half of the space, and 'female' subjects such as food technology and applied social health in the top half. The Indian ethnic group is located in the bottom left quadrant along with subjects such as maths with statistics and electronics. The Pakistani and Bangladeshi group is located in the bottom right quadrant with 'masculine' applied subjects such as applied engineering.

\section{FIGURE 5}

Axis 1: 53.47

Axis 2: 15.61

Students' choices are informed by many factors, including subject-specific self-concept and likes and dislikes. Their choices may also be either strongly or weakly informed by the advice of teachers and parents. The young people were asked how good they were at English, maths, science and Information Communication Technology (ICT), and how much they liked these subjects. They were also asked to what extent parents, teachers, and they themselves had determined their year 10 subject choices. The results of a Multiple Correspondence Analysis applied to these responses are shown in figure 5. The horizontal axis accounts for more than half of the inertia, and reflects self-concept and like or dislike for academic subjects, with high self-concept and likes on the left, and low self-concept and dislikes on the right. Perhaps surprisingly, all minority ethnic groups are located in the left of the space, with high selfconcept and liking for subjects. In the bottom left quadrant, we see that high self-concept and liking for both English and science are clustered with a lack of student choice, with choices being determined by parents and teachers. Young people whose parents have degrees are more likely to be located in this quadrant. The horizontal axis reflects the divide between English and maths, with liking English at the bottom, and liking maths at the top. This axis is predictably gendered.

\section{Conclusions}

The 'new' sociology of education of the 1970s proposed that the curriculum and what counts as knowledge should be the central questions to be addressed by sociologists of education 
(Young 1971). This movement was concerned primarily with critique rather than empirical work, and was criticised for raising philosophical rather than sociological questions (Pring 1972). It was attacked from a Marxist perspective, on the grounds that “...its relativist position with relation to knowledge...provides a new ideological means of denying to the working class access to knowledge, culture and science" (Simon 1976, p. 273). Young (1999, 2007) has recently acknowledged the force of this criticism, stating that it does disadvantaged children no favours to structure the curriculum around their knowledge, rather than allowing them to move beyond it; and acknowledging that the 'new' sociology of education failed to provide positive proposals regarding the curriculum. Subsequent sociological work has continued to argue that that the curriculum is implicated in educational inequalities (Whitty 1986), and that institutions play a role in shaping socially stratified curriculum tracks and 'choices' (e.g. Ball 1981, Gillborn and Youdell 2000). It is increasingly not only differences in the length of education that affect individual's life trajectories, but also differences in the type of education received (Lucas 2001). These differences are referred to as 'horizontal inequalities', as the subjects offered in school or chosen by individuals may affect chances to enter the most prestigious forms of employment or further education. The issue of inequality in access to the curriculum, and what this means for male and female students from diverse social classes, ethnic groups and types of school, has taken on a new salience due to the way in which students are now directed into varied curriculum paths from a young age. This differentiation is driven and justified by the discourse of 'diversity', 'choice', 'relevance' and 'personal learning'. Yet this rhetoric ignores the social structures within which students make their 'choices', and the potential consequences of these pathways for future inequalities in education, the labour market and the wider society.

The article presented here shows the ways in which the year 10 curriculum is socially structured. A gender divide remains, and is strongest in the vocational subjects. Black, Pakistani and Bangladeshi students are more likely than whites to take GCSE religion, and less likely to take triple-award sciences. Triple-award sciences and foreign languages are far more common at private schools. Multiple Correspondence Analysis shows the social hierarchy and gendered distribution of the subjects graphically.

Turning to the factors that influence students' choices at year 10, we looked at which subjects they liked and disliked most. Favourite and least favourite subjects were dramatically differentiated by gender, but far less so by parents' educational level. This suggests that the 
very different patterns of subjects taken by the children of graduates and non-graduates cannot be accounted for simply in terms of different tastes.

We also examined the reasons given for choosing particular subjects. These varied according to gender, parents' education and ethnicity. The responses of black, Pakistani and Bangladeshi students, and the children of non-graduates suggested that their choices were more constrained by instrumental factors. Contrary to the old idea that less privileged young people live for the present, while the middle-classes plan for the future, concerns about future courses and jobs appeared to weigh more strongly with the less privileged respondents.

Finally, we used MCA to analyse the structure of students' self-concept, likes and dislikes, and who informed their choices. The constellation of high self-concept, liking for academic subjects, and choices informed by teachers and parents together with graduate level parents, but also with minority ethnic status, suggests the way in which choices are shaped differently in a range of ways for young people of different backgrounds.

For us, this paper represents a first step in examining inequalities in the curriculum. We have shown that choices which are often characterized as individual are actually socially structured in a variety of ways. But we are conscious that our analyses raise many more questions that we do not have space to answer here. In future work, we hope to address some of these questions, such as the implications of early curriculum differentiation for later inequalities, including admission to selective universities. We also wish to develop our analyses to address issues of intersectionality, for example between ethnicity and gender. In addition, in future work, we intend to examine differences between types of institution in more detail. Geoffrey Walford's work examines the religious schools (Walford 2003a) and heterogeneity within the private school sector (Walford 2003b). Building on this, we will investigate school heterogeneity and the curriculum in future work.

Acknowledgements: We are grateful to Clare Baker at DCSF for assistance with the LSYPE data, and to the young people who participated in the LSYPE survey. Thanks also to the reviewers for their helpful comments. 


\section{References:}

Adkins, Lisaand Beverly Skeggs (eds). 2004. Feminism after Bourdieu: International Perspectives. Oxford: Blackwell.

Ball, Stephen J 1981. Beachside Comprehensive: A Case-Study of Secondary Schooling. Cambridge: Cambridge University Press.

Ball, Stephen J. 2003. Class Strategies and the Education Market: the middle classes and social advantage. London: Routledge.

Ball, S.B., D. Reay and M. David. 2002. 'Ethnic Choosing': minority ethnic students, social class and higher education choice Race Ethnicity and Education 5 no 4: 333 - 357.

BBC News Online 01/12/08 'Soft' A-level warning for pupils.

BBC News Online 28/04/09 English lit 'shunned by students'.

Bennett, Tony, Mike Savage, Elizabeth Silva Alan Ward, Modesto Gayo-Cal and David Wright. 2009. Culture, Class, Distinction. London: Routledge.

Benzecri, J.-P. 1973 L'analyse des Donnees: L'analyse des correspondences. Paris: Dunod. Bernstein, Basil. 1971 Class, Codes and Control, Volume 1. London: Routledge and Kegan Paul.

Blasius, J. and M. Greenacre. 2006. Correspondence analysis and related methods in practice. in Multiple Correspondence Analysis and Related Methods, ed. M. Greenacre, and J. Blasius, 3-40.London: Chapman and Hall.

Boudon, Raymond. 1974. Education, Opportunity and Social Inequality. New York: Wiley.

Bourdieu, Pierre. 1984 [1979] Distinction: A Social Critique of the Judgement of Taste. London: Routledge.

Bourdieu, Pierre. and Jean -Claude Passerson. 1977. Reproduction in Education, Society and Culture. London: Sage.

Bourdieu, Pierre. 2003[1984] Homo Academicus. Polity Press: Cambridge. 
Breen, R. and J.H. Goldthorpe. 1997. Explaining Educational Differentials: Towards a Formal Rational Action Theory. Rationality and Society 9 no 3: 275-305.

Chan, T.W. and J.H. Goldthorpe. 2007. Data, Methods and Interpretation in Analyses of Cultural Consumption: A reply to Peterson and Wuggenig. Poetics 35no 4/5: 317-329.

Davies, S. and N. Guppu. 1997. Fields of Study, College Selectivity, and Student Inequalities in Higher Education, Social Forces 75: 1417-1438.

Eccles, J.S. 1987. Gender roles and achievement patterns: An expectancy value perspective. In Masculinity/femininity: Basic Perspectives, eds. J.M. Reinish, L.A. Rosenbaum and S.A. Saunders.New York: Oxford University Press.

Fuller, A., V. Beck and L. Unwin. (2005) 'The gendered nature of apprenticeship: employers' and young people's perspectives', Education + Training 47 no 4/5:298-311.

Gayo-Cal, M., M. Savage and A. Warde. 2006. A Cultural Map of the United Kindom, 2003. Cultural Trends 15 2/3: 215-39.

Gillborn, David and Deborah Youdell. 2000. Rationing Education: Policy, practice, reform and equity. Buckingham: Open University Press.

Greenacre, M. 2006. From Simple to Multiple Correspondence Analysis. In Multiple Correspondence Analysis and Related Methods, eds. M. Greenacre and J. Blasius, 41-76.. London: Capman and Hall.

Hansen, M.N. and A. Mastekaasa. 2006. Social Origins and Academic Performance at University. European Sociological Review 22: 277-91.

Jacobs, J., P. Davis-Kean, M. Bleeker, J. Eccles and O. Malanchuk. 2005. "I can but I don't want to": The Impact of Parents, Interests and Activities on Gender differences in Math, in Gender Differences in Mathematics, eds. J. Kaufman, and A. Gallagher,. New York: Cambridge University Press.

Jacobs, Jerry A. 1989. Revolving Doors: Sex Segregation and Women's Careers. Stanford: Stanford University Press. 
Jackson, M., R. Luijkx, R. Pollak, L.-A. Vallet and H. Van de Werfhorst. 2008. Educational Fields of Study and the Intergenerational Mobility Process in Comparative Perspective? International Journal of Comparative Sociology 49 no 4/5: 369-388.

Kalmijn, M. and T. Van der Lippe. 1997. Type of Schooling and Sex Differences in Earnings in the Netherlands, European Sociological Review, 13: 1-15.

Kelly, A. 1985. The Construction of Masculine Science, British Journal of Sociology of Education 6 no 2. 133-54.

Kotecha, S. 2007. Unfamiliar with Higher Education: How bright students from nontraditional backgrounds make their choices. D. Phil Thesis, University of Oxford.

Le Roux, B., H. Rouanet, M. Savage and A. Warde. 2008. Class and Cultural Division in the UK. Sociology 42 no 6: 1049-1071.

Linver, M. R. and P.E. Davis-Keane. 2005. The Slippery Slope: What Predicts Math Grades in Junior High and High School?, New Directions for Child and Adolescent Development 110: 49-64.

Lucas, S. 2001. Effectively Maintained Inequality: Education Transitions, Track Mobility, and Social Background Effects, American Journal of Sociology, 106, No. 6: 1642-1690.

Modood, T. 2004. Capitals, Ethnic Identity and Educational Qualifications. Cultural Trends. 13 no 2: 87-105.

Power, Sally, Geoff Whitty, Tony Edwards and Valerie Wigfall 2003. Education and the Middle Class. Maidenhead: Open University Press.

Pring, R. 1972. Knowledge out of Control. Education for Teaching 89:19-28.Simon, B. 1976. Contemporary Problems in Educational Theory. In Intelligence, Psychology and Education: A Marxist Critique, ed. B Simon, 264-281 London: Lawrence and Wishart. Strand, S. 2007. Minority Ethnic Pupils in the Longitudinal Study of Young People in England (LSYPE). Research Report DCSF-RR002. 
Van de Werfhorst, H.G., Sullivan, A. And Cheung, S.Y. 2003. Social Class, Ability and Choice of Subject in Secondary and Tertiary Education in Britain. British Education Research Journal 29:41-62.

Savage, M. and M. Egerton. 1997. Social Mobility, Individual Ability and the Inheritance of Class Inequality. Sociology 31 no 4: 645-72.

Sullivan, A. 2001. 'Cultural Capital and Educational Attainment' Sociology. 35 no 4: 893912.

Sullivan, A. 2006. 'Students as Rational Decision-Makers: the question of beliefs and attitudes' London Review of Education 4 no 2: 271-290.

Sullivan, A. and L. Unwin. (forthcoming). Towards Compulsory Education in England. In International Studies of School Completion and Dropout: Research, Theory and Policy, eds. S. Lamb and R. Teese . Berlin: Springer/Verlag.

Walford, G. 2003. Separate schools for religious minorities in England and the Netherlands: using a framework for the comparison and evaluation of policy. Research Papers in Education, 18 no 3: 1-19.

Walford, G. 2003b. Introduction. In British Private Schools: research on policy and practice, ed. Geoffrey Walford, 1-8. . London: Woburn Press.

Whitty, G. 1985 Sociology and School Knowledge. London, Methuen.

Wuggenig, U. 2007. Comments on Chan and Goldthorpe: Pitfalls in testing Bourdieu's homology assumptions using mainstream social science methodology. Social stratification and cultural consumption: The visual arts in England. Poetics 35 no 4/5: 306-316.

Young, Michael_F.D. (Ed) 1971. Knowledge and Control: New Directions for the Sociology of Education. London: Macmillan.

Young, Michael F.D. 1999. The Curriculum of the Future: From 'New Sociology of Education' to a Critical Theory of Learning. London: Falmer Press.

Young, Michael F.D. 2008. Bringing Knowledge Back In: from social constructivism to social realism in the sociology of education London: Routledge. 
Zimdars, A., A. Sullivan and A. Heath. 2009. Elite Higher Education admissions in the Arts and Sciences: Is cultural capital the key, Sociology 43: 4, 648-666. 
Figure 1: Favourite and least favourite subjects by sex

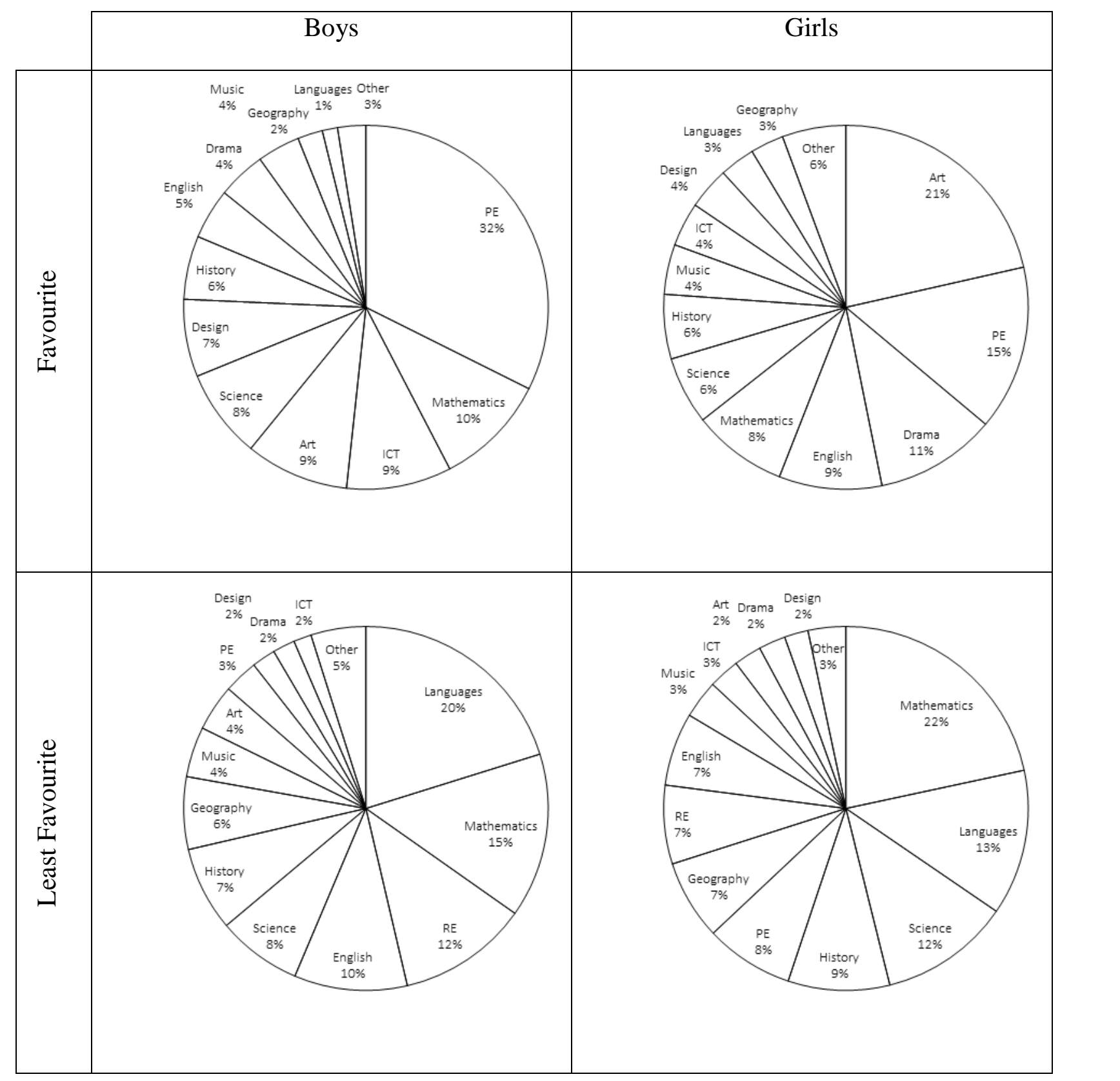


Figure 2: Favourite and least favourite subjects by parents' education

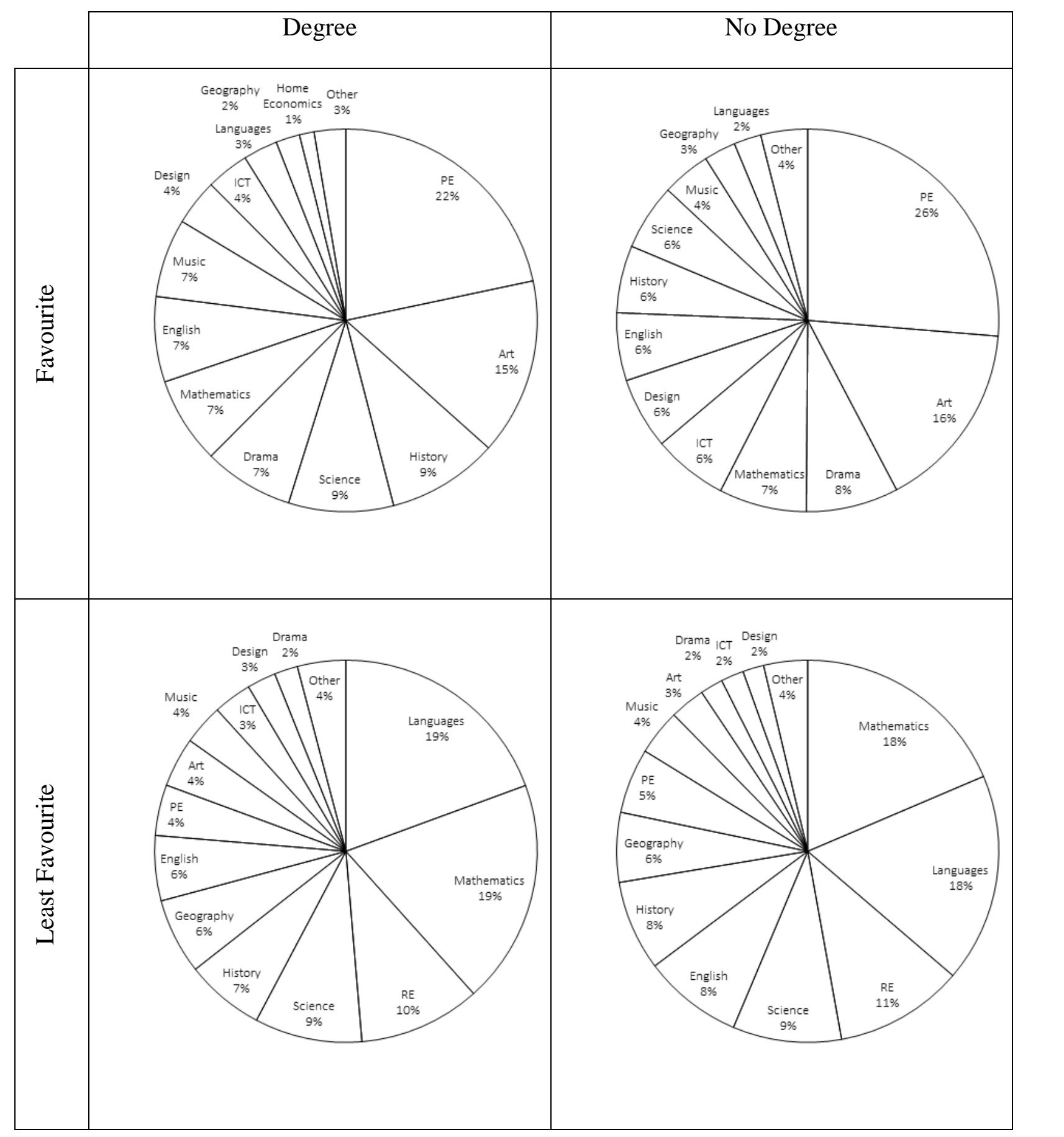


Figure 3a: Reasons for subject choice at age 14 by parental education

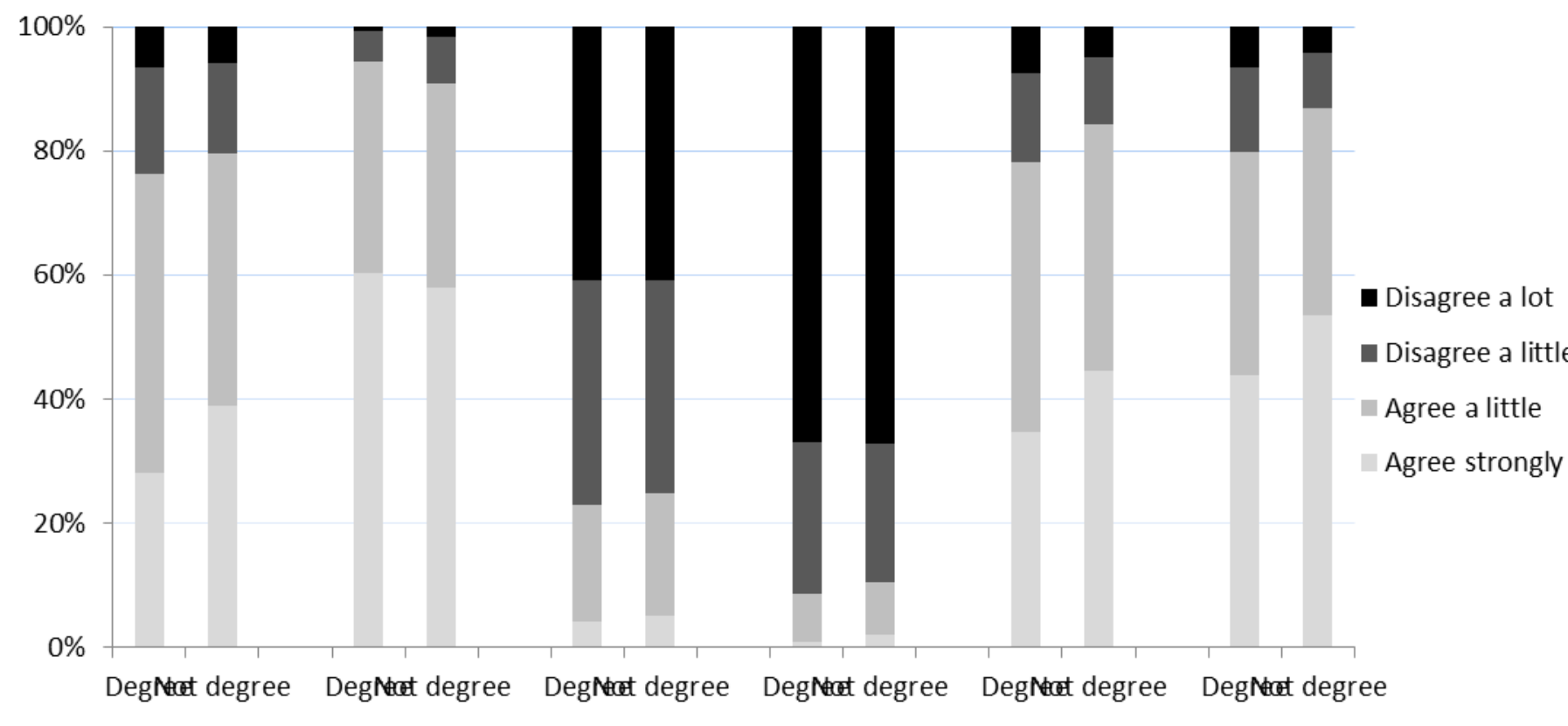

Do well in exams Interested like teacher same as friends for further education for career

Figure 3b: Reasons for subject choice at age 14 by gender

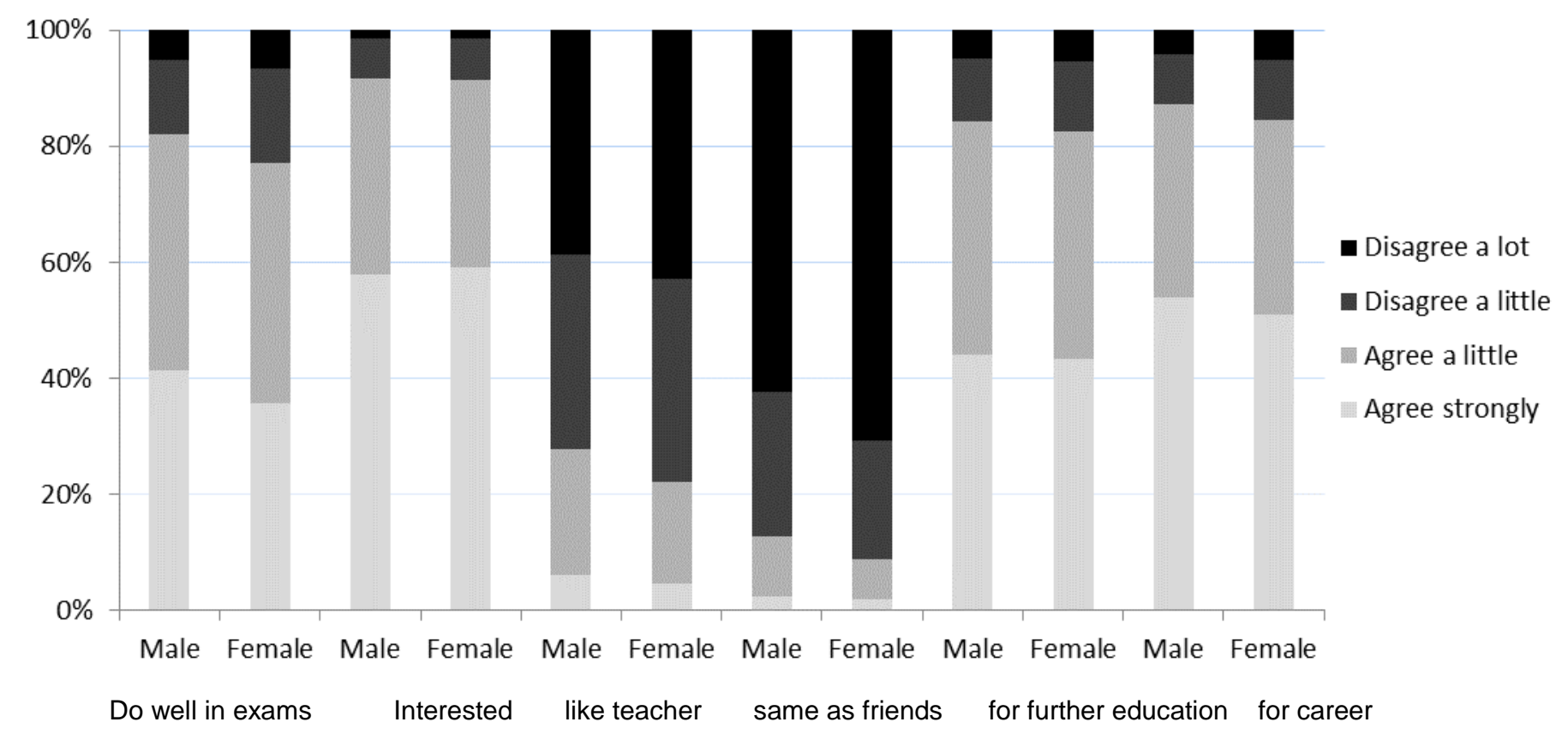


Figure 3c: Reasons for subject choice at age 14 by ethnicity

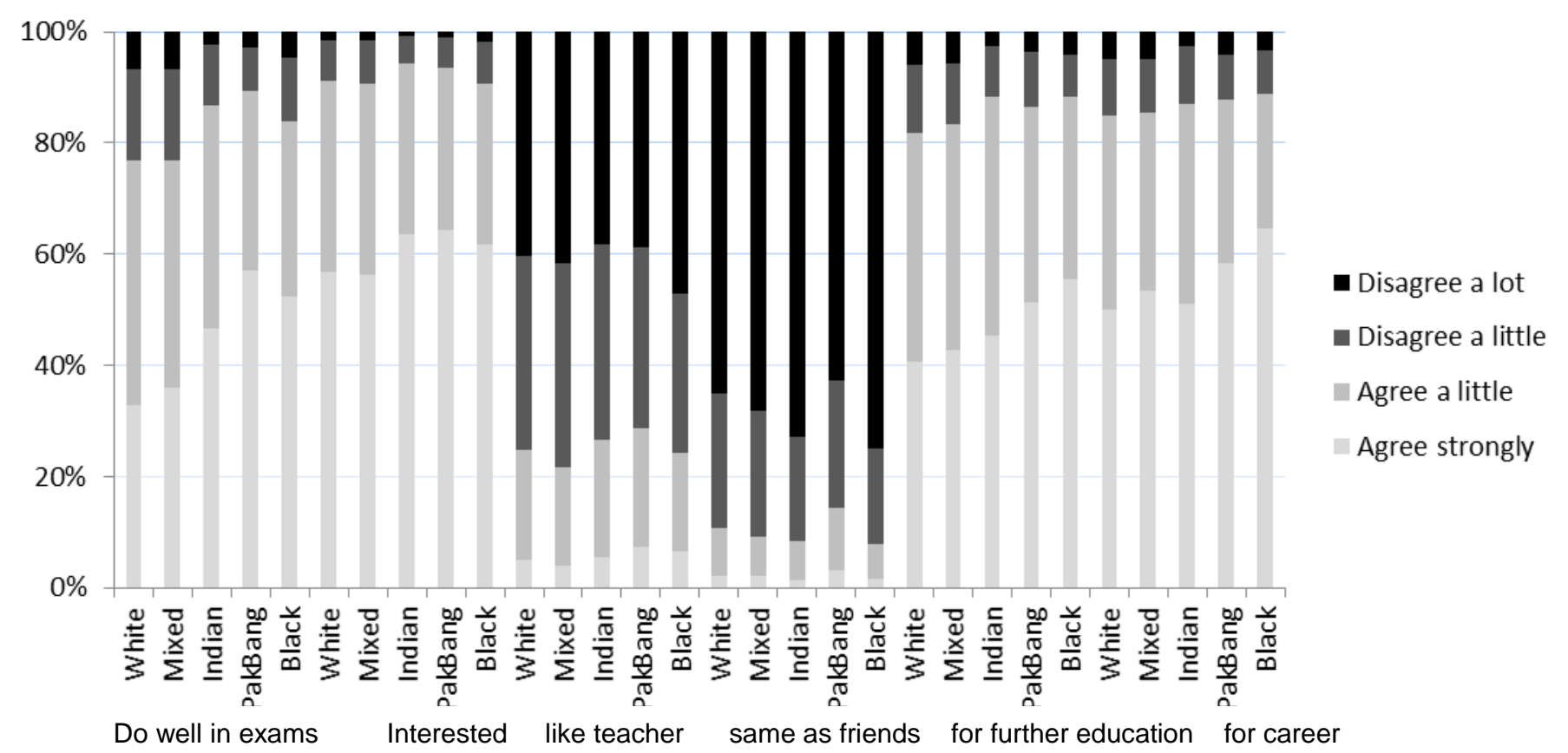


Figure 4: Year 10 subject choices

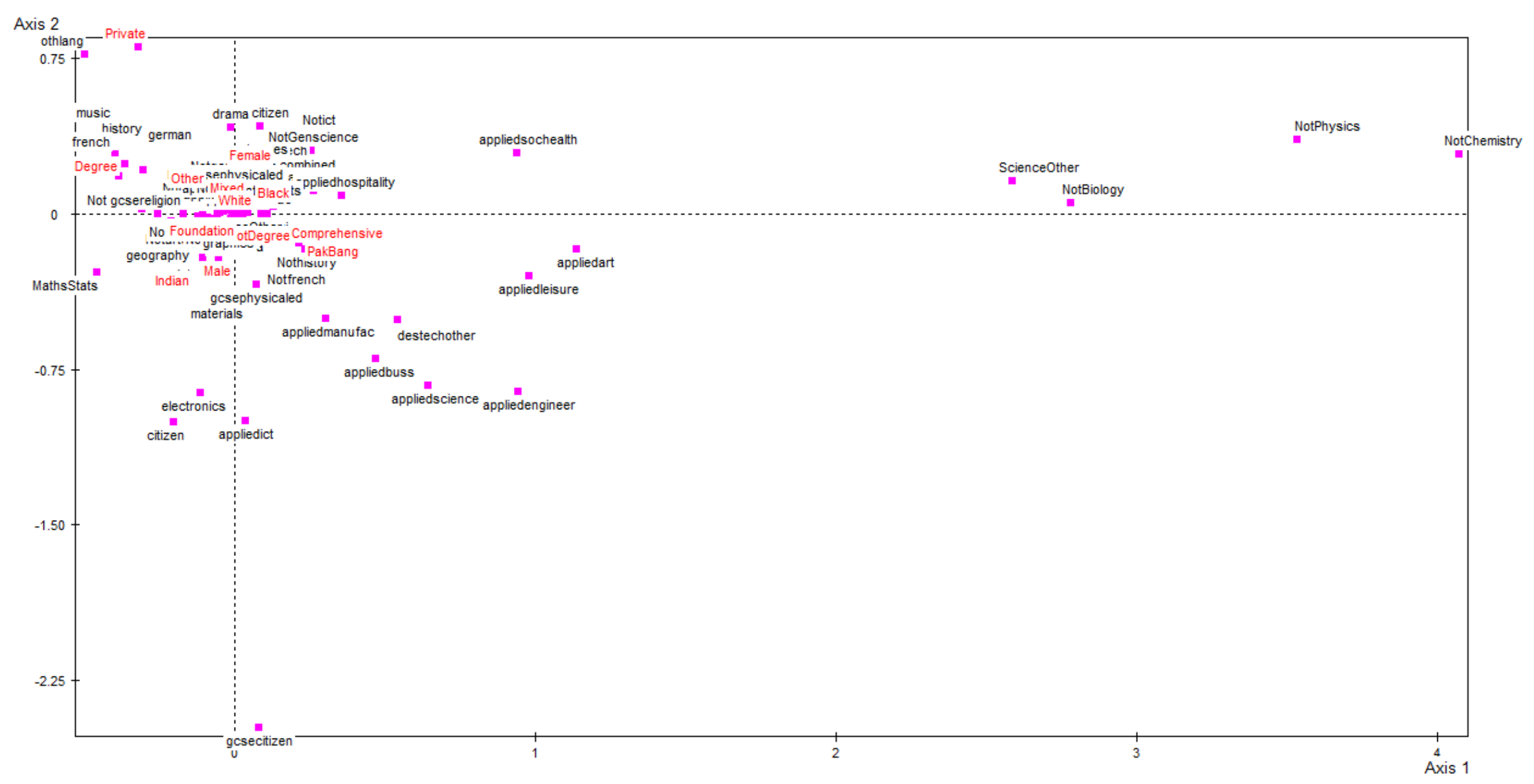


Figure 4b: Year 10 subject choices, magnification 


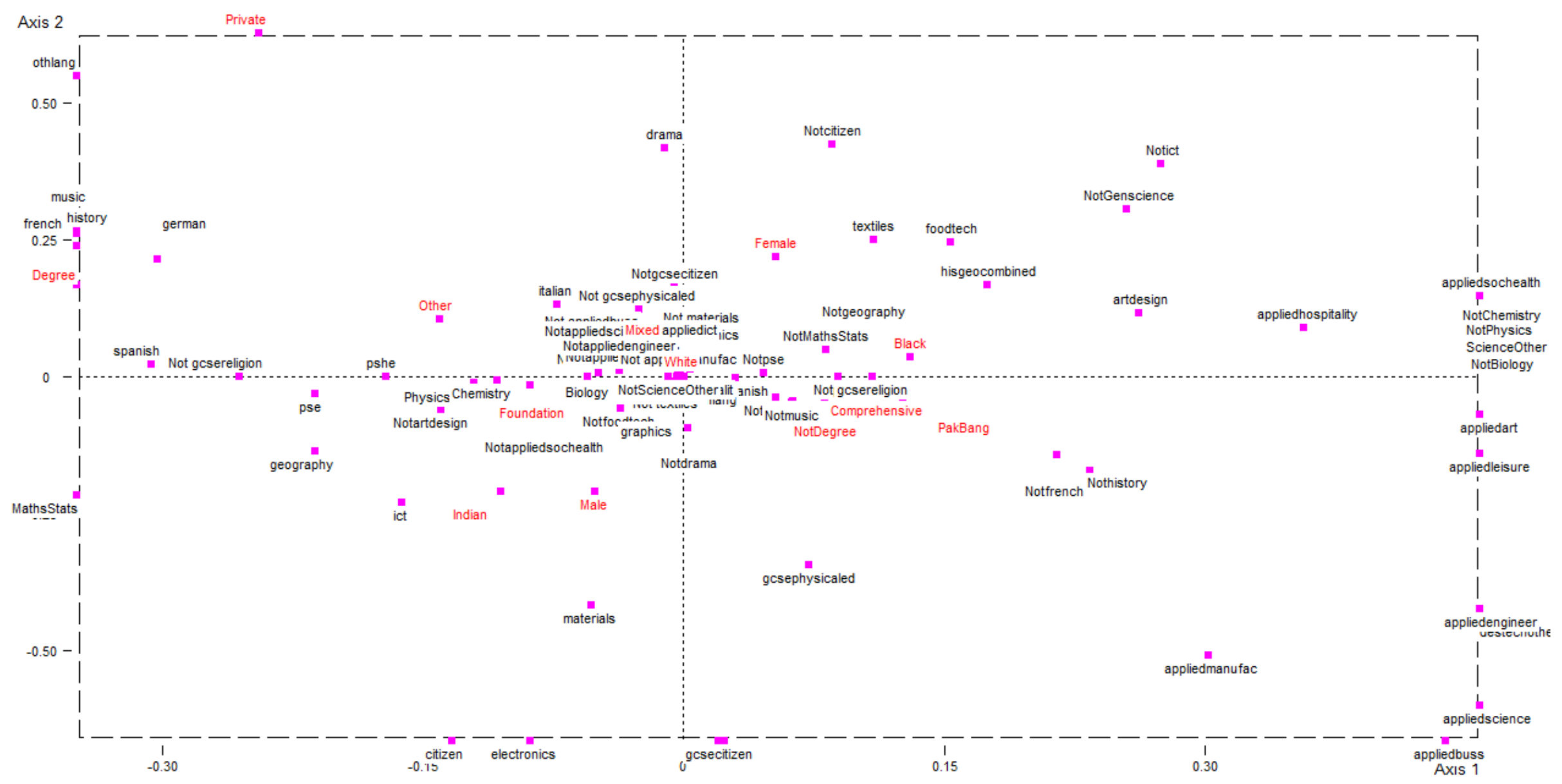


Figure 5: Factors informing choices

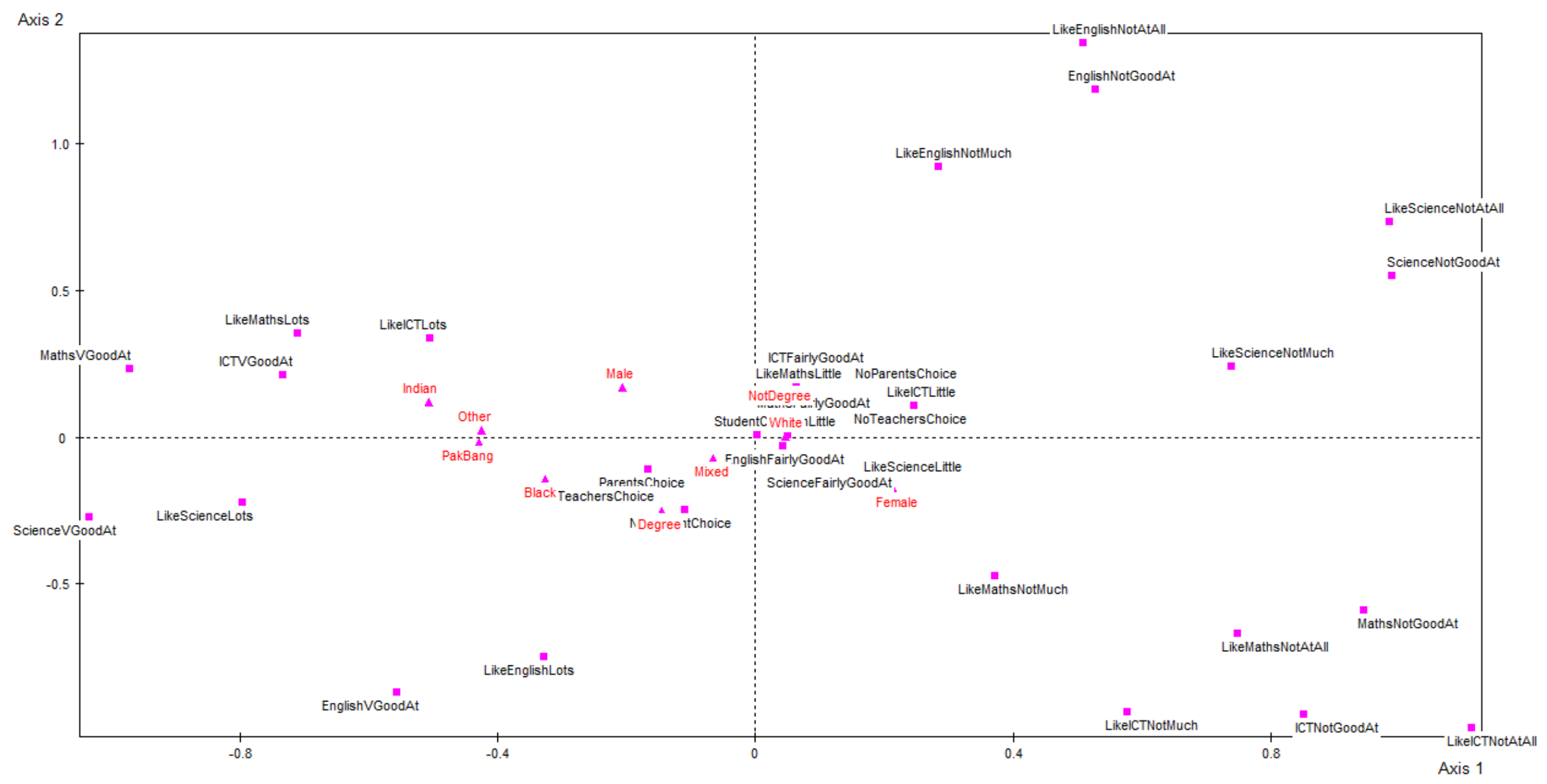


